\title{
Vegetation-environment relationships in a catchment containing a dambo in central Zimbabwe
}

\author{
I. MAPAURE* and M.P. MCCARTNEY**
}

Keywords: Canonical Correspondence Analysis, dambo. plant-water relations, vegetation classification, Zimbabwe

\section{ABSTRACT}

\begin{abstract}
Seasonally saturated wetlands. known as dambos, are a common landscape element throughout much of southern Africa. The diversity of species composition within catchments containing dambos is widely attributed to hydrological conditions, but plant-water relationships are poorly established. In this paper a detailed classification and a vegetation map are presented for a small catchment in central Zimbabwe containing a dambo. Canonical Correspondence Analysis has been applied to explore the link between vegetation composition and environmental variables. This confirms that water is a key influence in species distribution and small-scale patterning of vegetation within the catchment.
\end{abstract}

\section{INTRODUCTION}

Many factors influence the composition of vegetation. including the supply of nutrients, micro-climate, soil moisture, intraspecific competition, grazing and management practices (Gimingham 1972). In some environments, the relationship between water and vegetation has been shown to be particularly important. For example. Gurnell (1981) and Gurnell \& Gregory (1987) illustrated that the vegetation composition of heathland areas in temperate climates is particularly 'fine-tuned' to the underlying soil moisture regime. In a vegetation survey of Zimbabwe, Rattray (1957) concluded that soil moisture appeared to be the most important single factor affecting the distribution of grasses. Dye \& Walker (1980) illustrated how the influence of soil properties on the infiltration of water had a marked effect on floristic distribution in areas of Zimbabwe where sodic soils are prevalent.

Dambos (sometimes termed v leis) are seasonally waterlogged. predominantly grass covered. shallow depressions bordering headwater drainage lines. They are a widespread land feature in southern Africa. In Zimbabwe they occupy about $4 \%$ of the land surface (Whitlow 1984). Field observations indicate that soil moisture is one of the major variables influencing floristic variation within catchments containing dambos. Perera (1982) surmised that the most important controls on the distribution of plant communities within dambos are micro-relief. the water table and the physical and chemical properties of the soil. Whitlow (1985) states that within dambos vegetation generally comprises a mosaic of plant communities which changes in character from the margins to the central portions of the dambo dependent upon the degree and duration of waterlogging.

The current study is believed to be one of the first to statistically validate the relationship between vegetation

\footnotetext{
* Tropical Resource Ecology Programme. Deparment of Biological Sciences. University of Zimbabue. PO Box MP 167. Mount Pleasamt. Harare. Zimbatowe.

** Institute of Hydrology. Crowmarsh Gifford. Wallingford Oxfordshire OX10 8BB. UK

MS received: 1949-115-31
}

distribution and environmental factors for a dambo. There were two elements to the study. Firstly, a detailed vegetation classification and a vegetation map, based on floristic dominance and physiognomy. was derived for a small catchment in the highveld of central Zimbabwe. Secondly, the link between species composition and environmental variables was investigated independently of the mapping exercise using Canonical Correspondence Analysis (Ter Braak 1988a). The results indicate that vegetation associations may provide a basis for identifying characteristic soil moisture regimes in highveld catchments containing dambos.

\section{STUDY AREA}

The study area (Figure 1), is located in the headwaters of the Manyame River at the Grasslands Research Station, near Marondera. $70 \mathrm{~km}$ southeast of Harare. Relief over the catchment is low (gradients less than 4\%) and the elevation varies from $I 611$ to $1654 \mathrm{~m}$ above sea level. In Zimbabwe. land at elevations greater than 1200 $\mathrm{m}$ is known as highveld. The catchment area of $3.33 \mathrm{~km}^{2}$ comprises two parts: the upland region. known as the interfluve $\left(2.12 \mathrm{~km}^{2}\right)$ and a single dambo $\left(1.21 \mathrm{~km}^{2}\right)$. The dambo extends the whole length of the catchment and incorporates a narrow spur on the northern slope (Figure 1). This spur crosses the catchment boundary and joins another dambo in a neighbouring catchment. The main road and railway line from Harare to Mutare pass through the eastern end.

Rainfall is seasonal and largely dependent on the movement of the Intertropical Convergence Zone over southern Africa. Average annual rainfall is $859 \mathrm{~mm}$. hut varies considerably from year to year. Rainfall occurs predominantly during the wet summer (October to April). and the winter months (May to September) are usually dry. During the winter, the mean temperature is about $12.5^{\circ} \mathrm{C}$. although it is not uncommon for night temperatures 10 drop below freezing. During the summer. the mean temperature is $19.5^{\circ} \mathrm{C}$. Average potential evaporation is about $1700 \mathrm{~mm}$. 


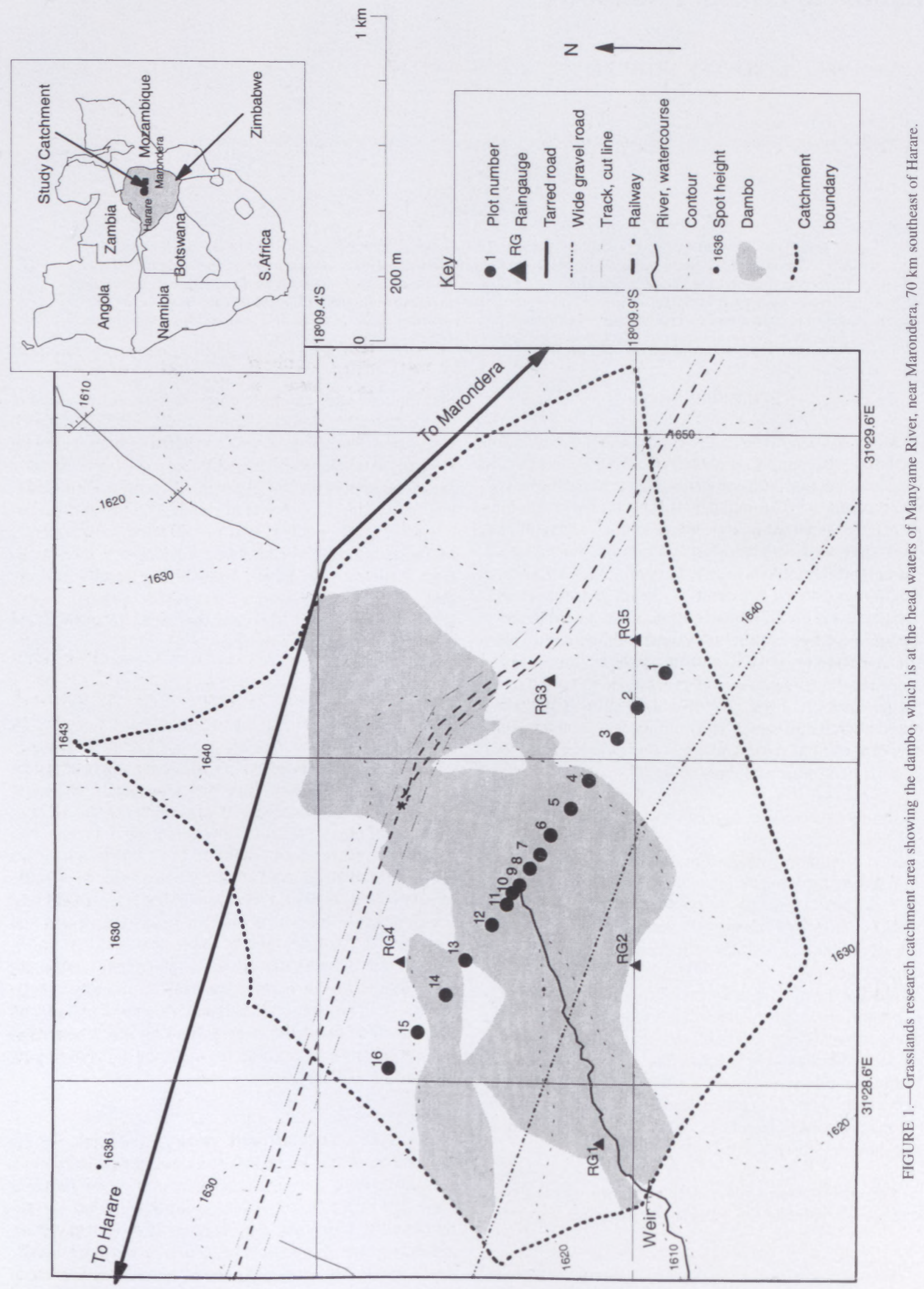




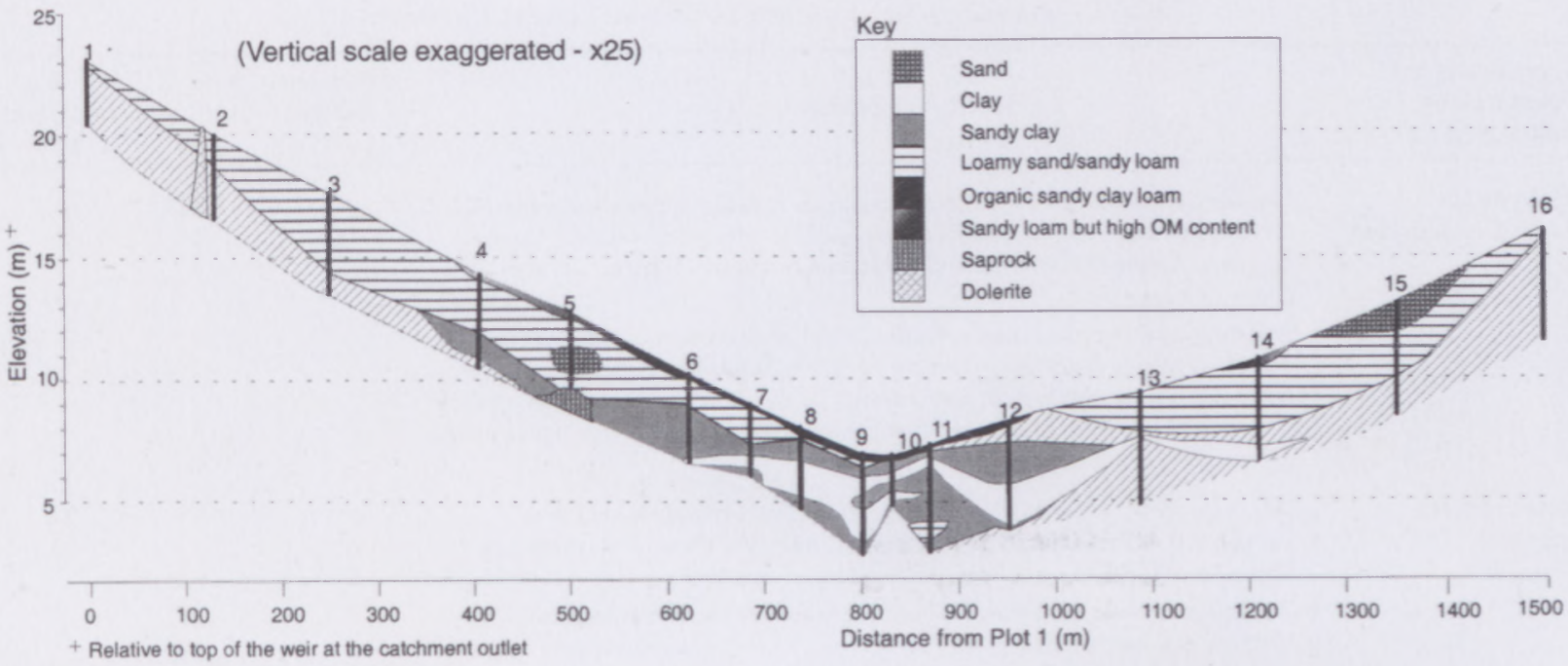

FIGURE 2.-Cross section showing soil profile, location of vegetation sampling plots and dipwells along transect across the grasslands research catchment, near Marondera.

Soils within the catchment have been derived predominantly from the underlying granite. However, in places, soil mineralogy and texture have been influenced by the presence of dolerite dykes. A distinct catena exists on the slopes of the catchment (Figure 2). The interfluve soils are acidic, strongly leached and have reached an advanced stage of weathering. They are moderately deep, coarse to medium-grained loamy sands overlying sandy clay loams. The dambo soils are hydromorphic with high organic matter content in the topsoils and gleying of the subsoils (Whitlow 1985). At shallow depth within the dambo, there is a well-defined clay wedge of irregular shape that is embedded within a lens of sandy clay. It is the presence of these heavy textured subsoils that impedes vertical drainage and results in the wet season saturation of the dambo.

\section{METHODS}

Two approaches were employed, one for vegetation mapping and the other for detailed environmental correlation. For vegetation mapping, inventory and classification, the method employed by Timberlake et al. (1993) was followed. Black-and-white aerial photographs (scale $1: 25000,1983$ ) were interpreted using a mirror stereoscope, and the vegetation was stratified on the basis of the textural differences on the photographs. To see if there were any significant changes since 1983 , aerial colour photographs were taken in the wet season of 1995. Sampling was done in both the dry and wet seasons. A total of 22 samples were randomly located in the stratified areas (stratified random sampling). At each sampling point all species were identified and their cover-abundance values assessed according to the Braun-Blanquet scale (Mueller-Dombois \& Ellenberg 1974). Since the number of samples was few and the size of the catchment area is small, it was possible to produce a floristic classification directly from the field sheets, in conjunction with both the black-and-white and the colour aerial photographs, without computer-aided classification.

For environmental correlations, detailed inventories were made of species within a radius of $5 \mathrm{~m}$ around each of 16 markers laid out along a transect across the middle of the catchment. The markers ran from the interfluve on the southern slope to the interfluve on the northern slope of the catchment crossing the valley bottom immediately to the east of the stream channel (Figure 1). Species presence/absence data were obtained, and later used to relate species composition directly to environmental variables measured within each plot.

Environmental factors were determined at each of the 16 plots. Soil characteristics determined for the surface soil horizon were: bulk density $(\mathrm{BDEN}), \mathrm{pH}\left(\mathrm{H}_{2} \mathrm{O}\right)$, electrical conductivity (EC) and percentage carbon (\%C). Dry bulk density was determined from the weight of undisturbed core samples oven dried at $105^{\circ} \mathrm{C}$ for 24 hours. Soil pH and EC were measured electrometrically in a 1:5 suspension in distilled water. The percentage of carbon in the soil was determined by the colorimetric method using potassium dichromate (Chapman 1987).

Within each plot, depth to the water table was measured daily from November 1995 to October 1996 in narrow diameter $(32 \mathrm{~mm}$ ) dipwells and the mean depth was calculated for each month. At each location, the mean value for February 1996 (February water table depthFWTD) was taken as an index of the wet season water level, and the mean level for September 1996 (September water table depth-SWTD) was taken as an index of the end of dry season water level. These were used as surrogate indicators of the soil moisture regime within each plot.

Species and environmental data from the 16 plots were subjected to Canonical Correspondence Analysis (CCA) (Ter Braak 1988b) to elucidate the relationships between vegetation composition and the six measured environmental variables. CCA is a direct ordination technique commonly used in community ecology studies. It integrates regression and ordination techniques into a method of multivariate direct gradient analysis that is used to detect unimodal relationships between species and environmental variables (Ter Braak 1986, 1987, 1988a). The relationships can be shown in an ordination diagram by vectors for the environmental variables with lengths proportional to their 
TABLE 1.-Summary of land cover in the Grasslands Research Catchment

Vegetation type determined by dominant species

Hyparrhenia filipendula grassland

Mixed channel grassland

Sporobolus subtilis grassland

Aristida junciformis grassland

Sporobolus pyramidal grassland

Mixed wooded grassland

Miombo woodland

Mixed woodland

Eucalyptus plantations

Cultivation and settlements
Grasses: Hyparrhenia filipendula, Setaria incrassata, Sporobolus pyramidalis, Loudetia simplex, Pogonarthria squarrosa, Hyperthelia dissoluta, Cynodon dactylon, Eragrostis chapelieri, Setaria pumila. Stereochlaena cameronii and Eragrostis superba

Woody species/weeds: Lannea edulis, Lopholaena coriifolia and Syzygium guineense subsp. huillense. Cinodon dactilon, Solanum delagoense, Bidens biternata, Tagetes minuta, Bidens pilosa, Conyza albida. Sesbania microphylla, Oldenlandia corvmbosa, Dactyloctenium aegvitium and Eleusine indica subsp. africana

Grasses/ sedges: Hemarthria altissima, Paspalum urvillei, Arundinella nepalensis, Aristida junciformis, Themeda triandra, Cyperus digitatus and Typha latifolius

Herbs: Ranunculus multıfidus, Verbena bonariensis, Senecio strictifolius, Helichrysum species, Kniphofia linearifolia and Polygonum senegalense Aquatic macrophyte: Potamogeton thunbergit

Grasses/sedges: Sporobolus subtilis, Pogonarthria squarrosa, Aristida junciformis, Arundinella nepalensis, Eragrostis capensis, Digitaria scalarum. Andropogon eucomus, Monocymbium ceresiiforme, Cyperus tenax and Kylinga erecta

Herbs/weeds: Bidens pilosa, Euphorbia cyparissoides, Oldenlandia herbacea, Conva welwitschii, C. albida and Tagetes minuta

Grasses/sedges: Aristida junciformis, Hyparrhenia filipendula, Andropogon gavanus, Digitaria scalarum, Sporobolus pyramidalis, Cyperus tenax, Sporobolus subtilis and Kyllinga erecta var. erecta

Herbs/weeds: Euphorbia cyparissoides, Ranunculus multifidus and Senecio strictifolius

Grasses/sedges: Sporobolus pyramidalis, Melinis repens, Eragrostis chapelieri. Selaria pumila, Dactyloctenium aegyptium. Pogonarthria squarrosa, Brachiaria deflexa, Cyperus esculenta and Kyllinga erecta and Cynodon dactylon

Wetter areas: Arundinella nepalensis, Andropogon eucomus. Pycreus aethiops, Aristida junciformis

Herbs/weeds: Haumaniastrum sericeum, Bidens pilosa and Ceratotheca triloba

Grasses: Hyparrhenia filipendula, Hyperthelia dissoluta, Pogonarthria squarrosa, Cinodon dactylon, Perotis patens, Heteropogon contortus and Eragrostis species

Shrubs: Eriosema ellipticum, Lopholaena coriffolia, Helichrysum kraussii, Pycnostachys urticifolia, Eriosema engleranum. Sida cordifolia, Parinari capensis, Syzygium guineense subsp. huillense, Pavetta schumanniana and Mavtenus senegalensis

Larger trees (mainly confined to termitaria): Brachystegia spiciformis,

Julbernardia globiflora. Syzvium guineense subsp. guineense and Acacia sieberiana

Trees: Brachystegia spiciformis, Julbernardia globiflora. Parinari curatellifolia. Cussonia arborea, Burkea africana and Ochna pulchra

Shrubs: Eriosema engleranum. Pavetta schumanniana, Lopholaena coriifolia. Helichrysum kraussii. Rhynchosia resinosa and Leptactina benguelensis Grasses: Sporobolus pyramidalis, Melinis repens and Pogonarthria squarrosa Weeds: Achyranthes aspera and Bidens pilosa. Amaranthus hybridus, Solanum delagoense and Datura stramonium

Trees: Combretum molle, Stnichnos spinosa, Burkea africana, Albizia antunesiana, Vangueria infausta, Cussonia arborea, Ekebergia benguelensis, Ozoroa insignis, Acacia sieberiana and Faurea speciosa

Shrub layer: Euclea crispa. Lippia javanica, Maytenus senegalensis, Eriosema ellipticum. E. engleranum. Pavetta schumanniana. Lopholaena coriffolia and Maytenus heterophylla

Grasses: Hyparrhenia filipendula, Pogonarthria squarrosa. Sporobolus pyramidalis, Aristida junciformis, Hiperthelia dissoluta and Perotis paten.

Exotic trees: Eucalyptus camaldulensis and other Eucalyptus species

Other trees: Julbernardia glohiflora, Brachystegia spiciformis and Pinus patula Indigenous shrubs: Eriosema engleranum. Pavetta schumanniana. Helichrisum kraussii, Gnidia kraussiana, Rhvnchosia resinosa, Lippia javanica, Indigofera arrecta, Blumea alata and Euclea crispa
$0.08 \quad 0.00$

2.4

$0.31-0.06$ chment

6.2


importance and directions showing their correlation with each axis. The statistical validity of the ordination was tested using an unrestricted Monte-Carlo permutation test available in CANOCO (Ter Braak 1988b).

\section{RESULTS AND INTERPRETATION}

\section{Vegetation classification}

The results of the vegetation classification are shown in Table 1 and mapped in Figure 3. The vegetation was classified into 10 types based on floristic dominance and physiognomy. Physiognomically, the types range from woodland through wooded grassland to grassland and plantations of exotic timber species. Physiognomic classes follow Pratt et al. (1966). A woodland is defined as a stand of trees with canopy cover of $20-80 \%$, a grassland is land dominated by grasses, sometimes with widely scattered herbs with canopy cover not exceeding $2 \%$, and a wooded grassland as grassland with scattered or grouped trees with canopy cover less than 20\% (Pratt et al. 1966). Woody species and grass nomenclature follow Drummond (1975) and Bennett (1980), respectively, with a few species name updates in both cases. Herb nomenclature follows various Flora zambesiaca volumes dealing with specific plant families.

Grassland is the most extensive of all the vegetation types in the catchment, covering $48 \%$ of the area. Six distinct types can be recognized, based on differing floristic dominance (Table 1). The most extensive is Hyparrhenia filipendula-dominated grassland. This is a medium-height grassland of up to $1.2 \mathrm{~m}$ high which extends from the channel grassland to the woodland and wooded grassland on the upper slopes. Very localized dominance of other grass species (i.e. Setaria incrassata, Sporobolus pyramidalis and Loudetia simplex) is also evident.

In the dambo itself, along the stream channel, there is a narrow belt, up to $10 \mathrm{~m}$ wide, characterized by grass and sedge species that can tolerate periodic waterlog- ging. Species dominance is not uniform, occurring in mosaics of local dominance of different species. The most common aquatic macrophyte is Potamogeton thunbergii which is quite abundant in pools in the channel.

Two patches of short grassland up to $1 \mathrm{~m}$ tall, dominated by Sporobolus subtilis, occur in the midslopes of the dambo area. Grass cover is generally high, with over $80 \%$ ground cover. The areas where this grassland is found become waterlogged during the rainy season and may remain so for long periods.

A patch of grassland dominated by Aristida junciformis occurs in the western part of the catchment area. Hyparrhenia filipendula is an important component of this grassland, becoming more or less co-dominant in some places. The grasses are generally short, most being less than $1 \mathrm{~m}$, and the cover is less than $70 \%$.

Sporobolus pyramidalis grassland is found on both well-drained soils on the upper slopes and on dark, heavy, periodically waterlogged soils closer to the valley bottom. It is composed of medium-height grasses of up to $1 \mathrm{~m}$ with more than $90 \%$ ground cover. In the wetter areas, Arundinella nepalensis becomes co-dominant.

Two patches of wooded grassland occur in the west of the catchment area. Larger trees, Brachystegia spiciformis, Julbernardia globiflora, Syzygium guineense subsp. guineense and Acacia sieberiana, are mainly confined to termitaria. The most common grass on termitaria is Cynodon dactylon.

Natural woodland occurs on the interfluve and covers about $12 \%$ of the catchment. Much of the miombo woodland is dominated by Brachystegia spiciformis which forms almost pure stands in places. The canopy cover is about $60 \%$. The canopy layer is up to $10 \mathrm{~m}$ high and consists of more or less even-aged trees. Scattered tall emergent trees are found in places. The shrub layer is sparse with occasional bare patches of ground.

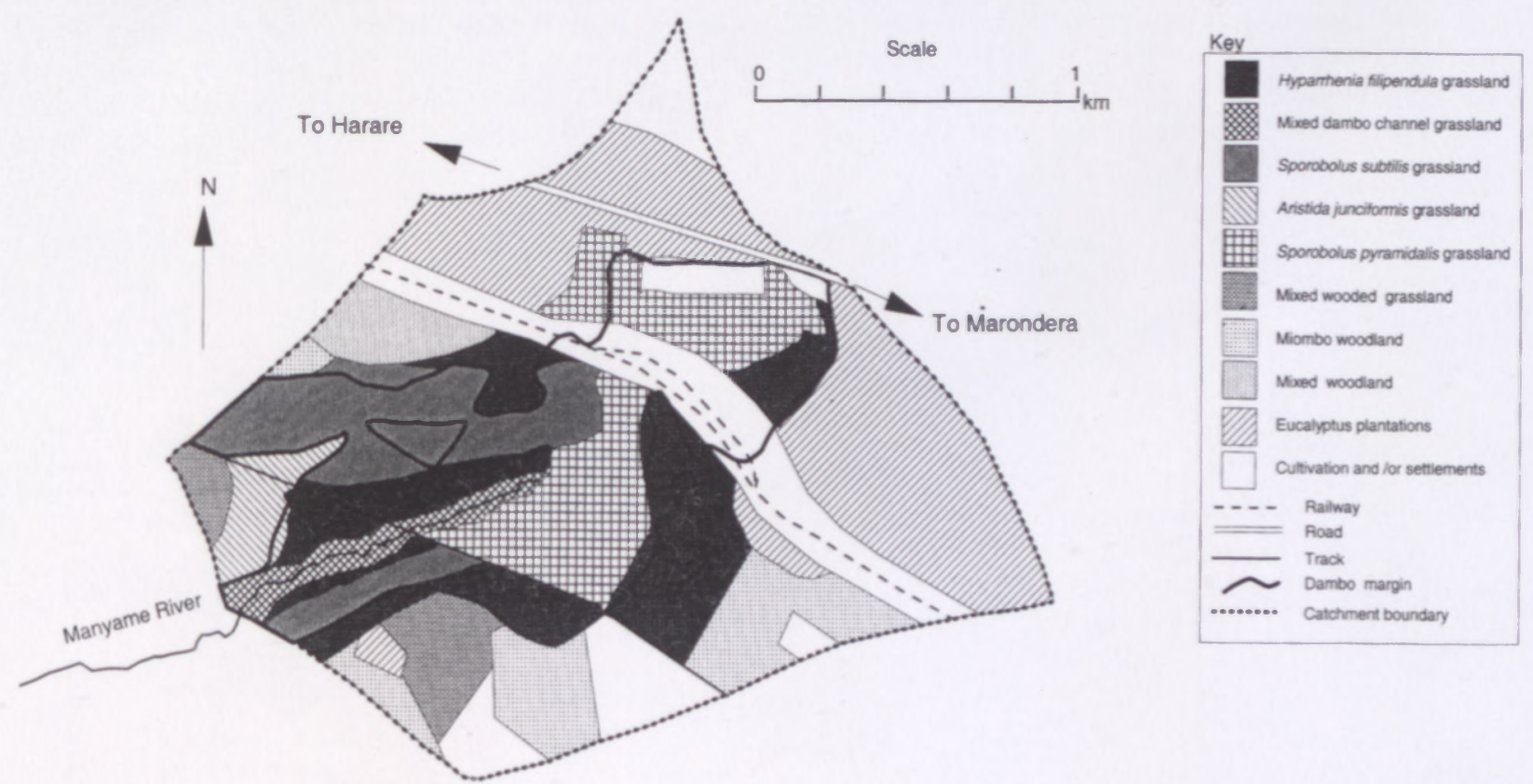

FIGURE 3.-Map showing vegetation types in grasslands catchment area near Marondera. 
One small patch of miombo woodland occurring in the northwest of the catchment area is somewhat different in character. Julbernardia globiflora is co-dominant with Brachystegia spiciformis and there are a significant number of large Parinari curatellifolia trees on the edges. The area is heavily disturbed by livestock and the shrub layer is very poor. The herb layer is characterized by high densities of Achyranthes aspera and Bidens pilosa.

A mixed woodland is found on the sandy soils in the northwestern part of the catchment area. It is a sparse woodland of up to $8 \mathrm{~m}$ with a canopy cover of $30-40 \%$. In some places it assumes the structure of a wooded grassland and comprises a mixture of species whose dominance varies from place to place. The most common trees in this woodland are Combretum molle. Strychnos spinosa, Burkea africana, Albizia antunesiana and Vangueria infausta.

Cultivated land and settlements occupy just over $16 \%$ of the catchment area. Much of the cultivation takes place either side of the railway line embankment, with other small areas close to settlements between the road and the railway (Figure 3 ). There is also some cultivation on the interfluve in the southwestern part of the catchment area. These fields are used by the Grasslands Research Station for experimental trials. In all the cultivated areas, the main crop is maize.

About $24 \%$ of the catchment, primarily either side of the dambo at the eastern end of the catchment, comprises plantations of exotic trees, particularly Eucalyptus camaldulensis and other Eucalyptus species. These are old trees (estimated to be at least 20 years) which have grown to heights of up to $30 \mathrm{~m}$.

\section{Vegetation-environment relationships}

A total of 63 species were encountered in the 16 detailed inventory plots. Each of the 16 plots was assigned to one of the 10 vegetation types identified in Table 1. Several plots (i.e. 2, 4 and 9 to 12) were located on or near the mapped lineation between vegetation types (i.e. in ecozone regions), but in all cases it was possible, through observation, to place each of them in one of the types. Of the natural vegetation types, only
TABLE 2.-Plot numbers of the vegetation types

\begin{tabular}{lc}
\hline \multicolumn{1}{c}{ Vegetation class } & Plot number \\
\hline Miombo woodland & 1 \\
Mixed woodland & 16 \\
Hyparrhenia filipendula grassland & $2,3,11,12$ \\
Mixed channel grassland & 9,10 \\
Sporobolus subtilis grassland & $13,14,15$ \\
Aristida junciformis grassland & - \\
Sporobolus pyramidalis grassland & $4,5,6,7,8$ \\
Mixed wooded grassland & - \\
Eucalyptus plantations & - \\
Cultivation and settlements & - \\
\hline
\end{tabular}

Aristida junciformis and mixed wooded grassland were not represented by any plots (Table 2 ).

The results of the CCA technique applied to the six environmental variables and 63 species, indicates that Axis 1 accounts for $84.6 \%$ of the observed variation in vegetation, whereas Axes 2, 3 and 4 account for $54.3 \%$. $48.6 \%$ and $38.7 \%$ respectively. Relationships between plots and Axes 1 and 2 are shown in Figure 4. The 16 plots were separated, by eye, into seven groups, two consisting of one plot each, four consisting of two or three plots each, and one with four plots.

There is greater separation of the groups along Axis 1 than along Axis 2. Group 1 are the plots in the dambo centre. Group II are the plots situated away from the dambo centre, but otherwise in wetter parts of the dambo. Group III contains the plots in drier parts of the dambo generally closest to the dambo-intertluve margin. and includes plot 14, which is located in the dambo spur. Group IV and V are the plots found in a more or less transitional zone between the woodland on the interfluve crest and the dambo grassland on the northern and southern slopes respectively. Groups VI and VII are both found in woodland on the interfluve crests, but differ in species composition. These groups are defined by characteristic indicator species (Table 3 ), generally conforming to those described by Whitlow (1985).

The analysis shows strong positive correlation between bulk density (BDEN) and September water table depth (SWTD) $(r=0.71)$, electrical conductivity (EC) and $\mathrm{pH}(\mathrm{r}=0.70)$, and percentage carbon $(\% \mathrm{C})$ and EC $(r=0.79)$. There is strong negative correlation

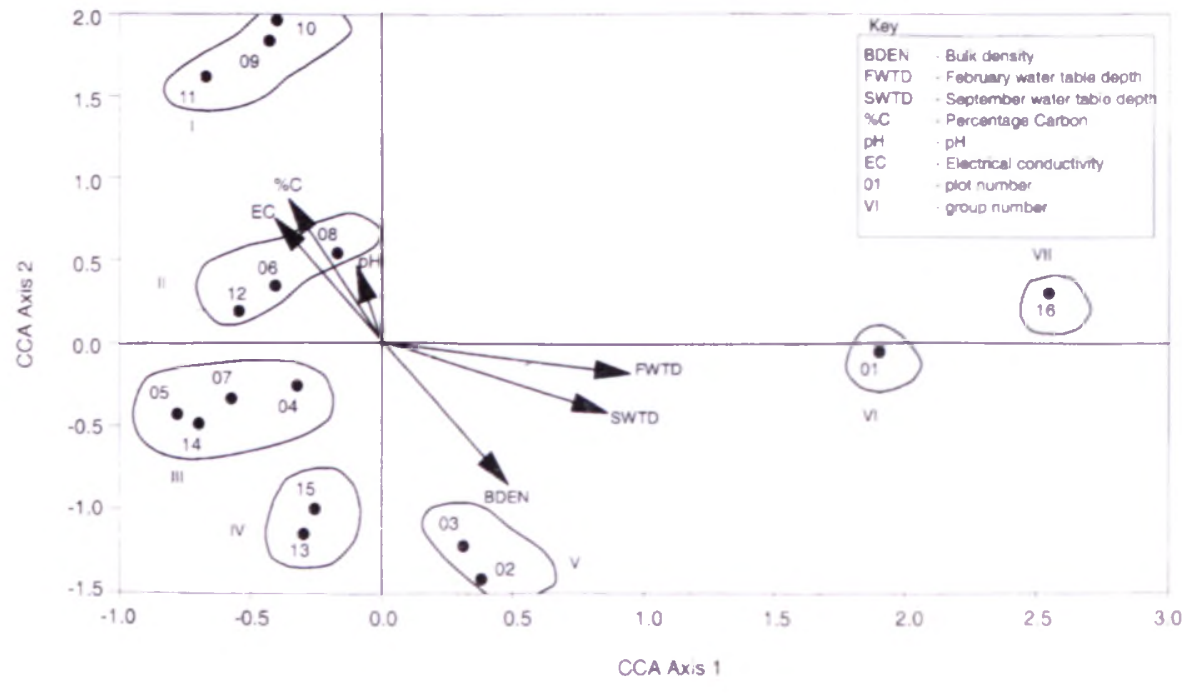

FlGURE 4 - Canonical Correypond ence Analysis ordinatlon showing the separation of the to plots 
TABLE 3.-Indicator species in identified groups

\begin{tabular}{llll}
\hline Group & Plots & Location & Indicator species \\
\hline I & $9,10,11$ & Dambo centre; valley bottom & Arundinella nepalensis, Aristida junciformis, Sporobolus subtilis \\
II & $6,8,12$ & Wet regions of dambo, but away from centre & $\begin{array}{l}\text { Sporobolus pyramidalis, Hyparrhenia filipendula } \\
\text { III }\end{array}$ \\
IV & $13,7,14$ & Dry regions of dambo & Sporobolus pyramidalis, Monocymbium ceresiiforme \\
V & 3,2 & Grassland on northern interfluve & Sporobolus subtilis, Hyparrhenia filipendula \\
VI & 1 & Interfluve crest, southern slope & Hyparrhenia filipendula, Melinis repens, Cynodon dactylon \\
VII & 16 & Interfluve crest, northern slope & Brachystegia spiciformis, Dicerocaryum senecioides \\
\end{tabular}

between BDEN and EC ( $r=-0.76)$, and BDEN and \%C $(r=-0.94)$. SWTD and February water table depth (FWTD) both show strong positive correlation with Axis $1(r=0.87$ and $r=0.96$, respectively). \%C and $\mathrm{EC}$ show positive correlations with Axis $2(r=0.88$ and $r=0.73$, respectively). BDEN shows a strong negative correlation with Axis $2(r=-0.83)$. The Monte-Carlo permutation test shows significant differences in floristic composition in relation to environmental variables $(p<0.01)$. However, the test is not significant for the first canonical axis alone. Plots 1, 2, 3 and 16 are more influenced by levels of the water table and the bulk density of the soil, whereas \%, $\mathrm{pH}$ and $\mathrm{EC}$ are more important determinants for the remaining plots, particularly those close to the dambo centre. The depth of the water table is much larger on the interfluve, where woodland predominates, than in the dambo, where grassland predominates (Figure 5).

\section{DISCUSSION}

\section{Vegetation classification}

The vegetation associations described in this paper represent two major structural types, woodland and grassland. The crests of the interfluves comprise woodland with a transition to grassland downslope. The dambo is entirely grassland. Ten vegetation types were defined and mapped on the basis of species dominance and composition.

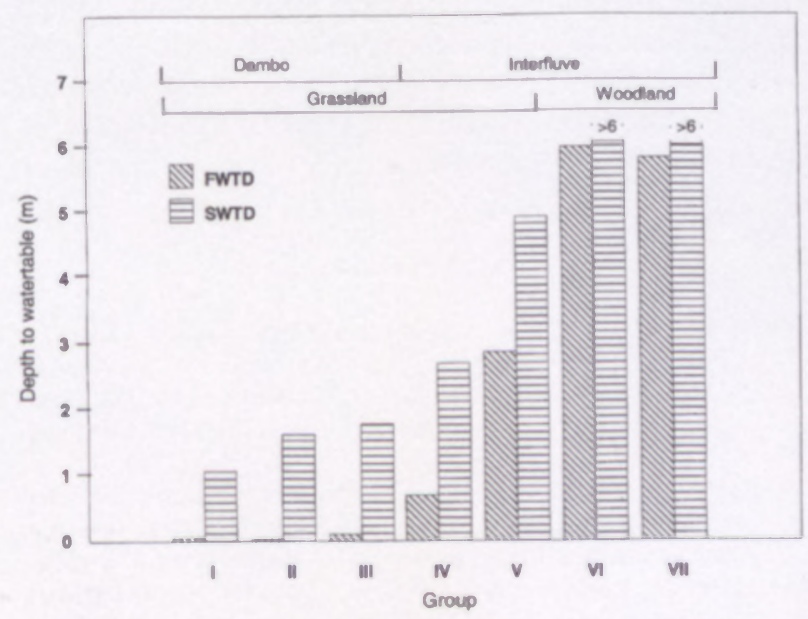

FIGURE 5.-Comparison of mean February water table depth (FWTD) and September water table depth (SWTD) for the seven vegetation groups shown in Figure 4.
A spatial successional sequence was observed along the catena from the woodland areas on the upper slopes down to the dambo channel. Definitive indicator species include Monocymbium ceressiiforme marking the dambo margin with woodland areas, while Sporobolus subtilis, Andropogon eucomus and Aristida junciformis dominate the wetter areas. The dambo centre vegetation is, however, different from that described by Whitlow (1985) and in the wetter regions, particularly towards the catchment outlet, it is characterized by Arundinella nepalensis, Verbena bonariensis and Euphorbia cyparissoides.

It is evident that the vegetation structure and composition have been influenced by past and present management practices in the catchment, particularly livestock grazing and land clearance for crop farming. Intensive grazing leads to changes in species composition with a tendency towards increasing dominance of unpalatable tuff grasses such as Sporobolus pyramidalis (Noy-Meir 1981; O'Connor 1995; Kennan 1969). It is, therefore, hypothesized that the current composition of the Sporobolus pyramidalis grassland is related to past management practices, and that it could have resulted from a gradual conversion of Hyparrhenia filipendula grassland owing to the impacts of grazing. Presently, cattle are stocked at about 3-4 hectares per livestock unit on a rotational basis ( $\mathrm{L}$. Lungu, late researcher at the Grasslands Research Station, pers. comm.). However, there is a tendency to concentrate animals in the paddocks close to the channel. Localized degradation effects by cattle on vegetation is further seen in the prevalence of weeds such as Bidens biternata, Tagetes minuta, Achyranthes aspera and Conyza albida in large sections of the grassland and under the trees in the miombo woodland.

The miombo woodland shows evidence of management. Campbell et al. (1995) described a miombo site in the area and noted that much of the woodland cover was removed after the establishment of the Grasslands Research Station in 1929. Subsequently, the area has been protected for the last 30 years which could explain the even-aged structure of trees noted in the present study.

\section{Vegetation-environment relationships}

There is a general trend of increasing soil depth to the water table from left to right along CCA Axis 1, which is also associated with increasing species woodiness. This is the key determinant separating dambo and interfluve vegetation; the former lying at the negative end and the latter lying at the positive end of Axis 1 . The only exception is Group IV which contains plots lying immediately 
up and down slope of the dambo spur on the northern side of the catchment. Although located on the interfluve this group falls on the negative end of Axis 1. However, in terms of water table regime this group is intermediate between the dambo and interfluve proper (Figure 5).

Within the dambo it is not possible to directly link floristic composition to February water table depth (FWTD) and September water table depth (SWTD). This may be because FWTD and SWTD have been derived from a single year's data which are atypical and do not reflect subtle long-term differences in the water table regime across the dambo. Interpretation is further complicated by management practices, which, as discussed above, have altered vegetation composition within the dambo. Nevertheless, a link between vegetation composition and soil moisture regime is revealed through the interrelationship between the identified groups and the other environmental variables used in the analysis. Figure 4 shows that the groups of dambo vegetation are spread along CCA Axis 2. Since there is a trend of increasing soil $\mathrm{pH}, \mathrm{EC}$ and $\% \mathrm{C}$ from the negative to the positive end of Axis 2, these are the key environmental variables associated with differences in species composition within the dambo. However, $\mathrm{pH}$ and $\mathrm{EC}$ are highly correlated with organic matter content (expressed as \% C) which is largely governed by the extent and duration of waterlogging (Savory 1965). It is therefore probable that, over long periods of time, the variation in floristic composition would correlate with differences in water table regime. Thus, while not directly identified by FWTD and SWTD, it is very likely that differences in vegetation composition within the dambo are influenced by subtle variation in the water table regime over time. Considering the whole catchment, it is evident that the amount of soil moisture and extent of waterlogging are major factors influencing vegetation composition.

Comparison of Tables 2 and 3 reveals that in several of the groups identified in the CCA. plots located in more than one of the natural vegetation classes identified independently in the classification and mapping exercise. For instance, Group 1 comprises Plots 9 and 10 which occur in the region classified as mixed dambo channel grassland, as well as Plot 11 which is located in region of Hyparrhenia filipendula grassland. Similarly, in Group II. Plots 6 and 8 lie in a region classified as Sporobolus pyramidalis grassland, but Plot 12 occurs in a region classified as Sporobolus subtilis grassland, while in Group III. plots 4, 5 and 7 are in a region classified as Sporobolus pyramidalis grassland, but Plot 14 is located in a region of Sporobolus subtilis grassland. Nevertheless. within each group. the majority of the plots lie within one type. as shown in Table 4.

TABLE 4.-Links between vegetation type and group

\begin{tabular}{ll}
\hline Group & Vegetation Type \\
\hline I & Mixed channel grassland \\
II & Sporoholus pyramidalis grassland \\
III & Sporoholus pyramidalis grassland \\
IV & Sporobolus subtilis grassland \\
V & Hyparrhenio grassland \\
VI & Miombo woodland \\
VII & Mixed woodland
\end{tabular}

These results indicate that there is a strong, but not unambiguous, correspondence between the mapped vegetation classes and the environmental variables identified by the CCA which are associated with floristic composition. The lack of a clearer relationship can be attributed to two factors. Firstly, the common link between plots within a group are the indicator species rather than the dominant species which identify the class. Secondly, plots are effectively spot samples and may not be truly representative of the vegetation of the area within which they are situated. This second factor in particular explains the lack of correspondence for those plots that lie in ecozones, where the vegetation is transient between vegetation types.

\section{CONCLUSION}

Although land management policies have influenced vegetation composition to some extent, there is nevertheless a clear relationship between vegetation composition and environmental variables within the catchment. The amount of soil moisture and extent of waterlogging (as indicated by the levels of the water table in the wet and dry seasons) is the overriding factor distinguishing the floristic composition of the interfluve and the dambo. Furthermore, within the dambo, the study findings strongly suggest that the extent and duration of waterlogging is a key influence in determining the presence/absence of indicator species.

The results strongly support qualitative observations made elsewhere in Zimbabwe. Subtle differences in soil moisture resulting from slight variation in water table regime can result in noticeable differences in vegetation composition. The relationship between the identified vegetation classes and the environmental variables used in the CCA suggests that with additional data collection and analysis, vegetation associations may provide a basis for identifying characteristic soil moisture regimes in similar highveld catchments containing dambos.

\section{ACKNOWLEDGEMENTS}

This research was partly funded by the UK Natural Environment Research Council through the Dambo Processes Integration Experiment. Alfred Maroyi of the National Herbarium. Harare. helped with botanical tieldwork. Luckmore Chigwaze of the Horticultural Research Centre, Marondera assisted with field measurement of the environmental variables.

\section{REFERENCES}

BENNETT. KE. 1980) Kev to Zimbabwean grass species. Kirkia II $169-286$.

CAMPBELL. B.M. CLNIIFFE. R.N. \& GAMBIZA, J. 1995. Vege lation structure and small-scale patlern in miomber wordland. Marondera. Zimbabwe. Bothalia 25:121-126.

CHAPMAN, DJ. 1987. Soil sune's: methexts of analses for soils Unpublished report to Department of Revearch and Specialist Services, Soils \& Chemistn Rexearch Inscitute. Harare, Zimbabwe

DRUMMONI), R.B. 1975. A list of trees, shrubs and wockly climbers indigenous or naturalised in Rhexdesial. Kirkice 10: 229-285

DYE, PJ. \& WALKER, B.H. 1980. Vegetation-environment relations on sodic soils of Zimbabuc Rhodesia. Journal of Eoologe o8 $589.60 \%$. 
GIMINGHAM. C.H. 1972. Ecology of heathlands. Chapman \& Hall, London.

GURNELL, A.M. 1981. Heathland vegetation, soil moisture and dynamic contributing area. Earth Surface Processes and Landforms 6: $553-570$.

GURNELL, A.M. \& GREGORY. K.J. 1987. Vegetation characteristics and the prediction of runoff: analysis of an experiment in the New Forest, Hampshire. Hydrological Processes 1: 125142.

KENNAN. T.C.D. 1969. A review of research into cattle-grass relationship in Rhodesia. Proceedings of the veld management conference: 5-28. Government Printers, Salisbury.

MUELLER-DOMBOIS, D. \& ELLENBERG, H. 1974. Aims and methods of vegetation ecology. John Wiley, New York.

NOY-MEIR, 1. 1981. Responses of vegetation to the abundance of mammalian herbivores. In P.A. Jewel \& S. Holt, Problems in management of locally abundant wild animals: 233-246. Academic Press, New York.

O'CONNOR. T.G. 1995. Transformation of a savanna grassland by drought and grazing. Journal of Range and Forage Science 12: $53-60$.

PERERA. N.P. 1982. The ecology of wetlands (dambos) of Zambia and their evolution for agriculture - a model for the management of wetlands in subhumid eastern and southem Africa. International Journal of Ecology and Environmental Science 8: 27-38.

PRATT. D.J., GREENWAY. P.J. \& GWYNNE. M.D. 1966. A classification of East African rangeland, with an appendix on termi- nology. Journal of Applied Ecology 3: 369-382.

RATTRAY. J.M. 1957. The grasses and grass associations of Southern Rhodesia. Rhodesia Agriculture Journal 54: 197-234.

SAVORY. R.M. 1965. The relationship of soil development to water table levels in a granitevlei at Marandellas, Southern Rhodesia. Unpublished M.Sc. (Agriculture) thesis, University of London.

TER BRAAK. C.J.F. 1986. Canonical Correspondence Analysis: a new eigenvector technique for multivariate direct gradient analysis. Ecology 67: 1167-1179.

TER BRAAK. C.J.F. 1987. The analysis of vegetation-environment relationships by Canonical Correspondence Analysis. Vegetatio 69: 69-77.

TER BRAAK, C.J.F. 1988a. CANOCO-an extension of DECORANA to analyse species environment relationships. Vegetatio $75: 159$. 160

TER BRAAK. C.J.F. 1988b. CANOCO-a Fortran program for canonical community ordination by [partial] [detrended] [canonical] correspondence analysis, principal components analysis and redundancy analysis (Version 3.1). Agricultural Mathematics Group. Technical report. Wageningen.

TIMBERLAKE, J., NOBANDA. N. \& MAPAURE. I. 1993. Vegetation survey of the communal lands-north and west Zimbabwe. Kirkia 14: 171-270.

WHITLOW. J.R. 1984 A survey of dambos in Zimbabwe. Zimbabwe Agricultural Journal 81: 129-138.

WHITLOW. J.R. 1985. Dambos in Zimbabwe: a review. Zeitschrift fur Geomorphologie Supplementband 52: 115-146. 